\title{
"Eu faço a paz e crio o mal": aproximações exegéticas do livro do profeta Isaías
}

\author{
Taciana Brasil*
}

\section{Resumo}

Sabemos que toda tradução é um esforço de interpretação. Por mais que um tradutor se esforce, é possível que elementos primordiais do sentido original se atenuem durante este processo. A exegese permite ao leitor maior aproximação do texto bíblico. Este artigo almeja, através dessa metodologia, compreender melhor um versículo do livro de Isaías (45.7). A pesquisa foi dividida em quatro temas: o profeta e seu livro, aspectos linguísticos, aproximações com o vocabulário do Pentateuco e verificação de algumas traduções bíblicas comercializadas no Brasil. Concluímos que o texto ressalta o poderio divino, expresso nos verbos relacionados à atividade criadora. Percebemos ainda que as melhores traduções procuram se aproximar do texto através da literalidade ou da interpretação teológica, permitindo leituras adequadas.

Palavras-chave: Isaías. Pentateuco. Exegese. Primeiro Testamento. Hebraico.

\section{"I make peace, and create evil": exegetical approaches to the book of the prophet Isaiah}

\begin{abstract}
Every translation is an effort of interpretation. Despite the translator's effort to maintain the original meaning, it is possible that key elements of the original meaning are attenuated during this process. Exegesis brings the biblical text closer to the reader. This article aims, through this methodology, to better understand a verse from the book of Isaiah (45.7). The research was divided into four themes: the prophet and his book, linguistic aspects, approximations with the vocabulary of the Pentateuch and verification of some biblical translations marketed in Brazil. We conclude that the text emphasizes the divine power, expressed in the verbs related to the creative activity. We also realized that the best translations seek to approach the text through literalness or theological interpretation, allowing for adequate readings.
\end{abstract}

Keywords: Isaiah. Pentateuch. Exegesis. Old Testament. Hebrew language.

\footnotetext{
FONAPER (Fórum Nacional Permanente de Ensino Religioso. Doutora em Ciências da
} Religião, Mestre em Educação, pedagoga e teóloga. tacianabrasil@yahoo.com.br . 


\section{"Yo hago la paz y creo el mal": enfoques exegéticos al libro del profeta Isaías}

\section{Resumen}

Sabemos que cada traducción es un esfuerzo de interpretación. Por mucho que un traductor lo intente, es posible que los elementos primordiales del significado original se atenúen durante este proceso. La exégesis acerca el texto bíblico al lector. Este artículo tiene como objetivo, a través de esta metodología, comprender mejor un versículo del libro de Isaías (45.7). La investigación se dividió en cuatro temas: el profeta y su libro, aspectos lingüísticos, aproximaciones con el vocabulario del Pentateuco y verificación de algunas traducciones bíblicas comercializadas en Brasil. Concluimos que el texto enfatiza el poder divino, expresado en los verbos relacionados con la actividad creativa. Sin embargo, nos dimos cuenta de que las mejores traducciones tratan de acercarse al texto a través de la interpretación literal o teológica, lo que permite lecturas apropiadas. Palavras clave: Isaías. Pentateuco. Exégesis. Primero Testamento. Hebreo.

\section{Introdução}

A leitura do texto bíblico pode assumir diversos sentidos e funcionalidades. Para alguém, ele tem estrito caráter devocional e pessoal. Outra pessoa o vê como instrumento para construção de um pensamento teológico fundamentado. Ao terceiro indivíduo, ele é visto como literatura quer esse indivíduo o identifique como sagrado ou não. Em comum, esses leitores possuem o fato de não serem o público alvo a quem se dirigiu o texto, há muitos séculos atrás. Dessa forma, sua leitura necessariamente produz uma compreensão que não foi prevista pelo escritor do texto (SILVA, 2003).

Silva (2003) agrupa os níveis de interpretação do texto bíblico em cinco direcionamentos ou níveis de leitura, a saber: oração - liturgia - catequese teologia - exegese. Neste trabalho, interessa-nos a leitura no nível exegético, que se caracteriza pela busca da compreensão das ideias, intenções e forma literária do texto bíblico, bem como de sua relação formal com outros textos.

De acordo com Virkler (1998), é possível compreender o que é a exegese através da etimologia da palavra: "O prefixo ex ('fora de', 'para fora', ou 'de') refere-se à ideia de que o intérprete está tentando derivar seu entendimento do texto, em vez de ler seu significado no ('para dentro') texto (eisegese)." (VIRKLER, 1998, p. 11, aspas originais). Silva (2003) ressalta que uma exegese deve considerar os aspectos linguísticos do texto, tais como fonética, morfologia, sintaxe e estilo, bem como o sistema sígnico em que o mesmo foi produzido, e as condições de leitura nos dias atuais.

Este trabalho se ocupa, especificamente, de um versículo contido no livro de Isaías (45.7). Longe de ser uma pesquisa exaustiva sobre o trecho, 
procuramos enfocar os verbos que remetem à atividade criadora. Para compreender o significado atribuído aos mesmos por seus leitores originais, foi feita uma análise comparativa da utilização das formas verbais no Pentateuco, verificando o contexto e o sentido que as raízes tinham no texto mais antigo, para então avaliar como as mesmas são utilizadas na releitura profética. Comparamos, então, esses resultados com algumas das traduções bíblicas mais populares no país, verificando se sua leitura promove uma compreensão mais aproximada ou distanciada do sentido original dos textos.

Os resultados da pesquisa estão organizados em quatro tópicos. $\mathrm{O}$ primeiro procura apresentar o livro de Isaías, contextualizando sua atuação como profeta. O segundo se dedica aos aspectos linguísticos do texto. O terceiro estabelece uma comparação entre a utilização das raízes verbais relacionadas à atividade criadora no Pentateuco e no texto em questão. $\mathrm{O}$ último compara os resultados da pesquisa a algumas das traduções bíblicas comercializadas no Brasil.

\section{O profeta Isaías}

A profecia era um fenômeno comum no Oriente Próximo. Na Assíria, sacerdotisas profetizavam em transe no templo de Ishtar. Em Canaã, encontramos referências no próprio livro de Gênesis ao uso de árvores sagradas, como os carvalhais de Moré (12.6). Em Mari, na Mesopotâmia, foi encontrado um conjunto de cartas escritas no século 18 a.C. que transcreviam um conjunto de oráculos, resultados de perguntas propostas a uma divindade (PETERLEVITZ, 2008).

De acordo com Sicre (1998), em Israel e em todo o Oriente Próximo era esperado que o profeta fosse um homem capaz de predizer o futuro, graças a seu relacionamento próximo com alguma divindade. O indivíduo que consultava um profeta almejava receber uma revelação do que lhe ocorreria. Eventualmente, poderia também receber uma missão dada pela divindade.

Conforme este autor, o diferencial entre os oráculos transmitidos por interesses pessoais e os que realmente representavam uma revelação do Deus apresentado como verdadeiro no Primeiro Testamento era o fato de que estes não se isentavam de oferecer a resposta que manifestasse a vontade divina, mesmo que contrariasse interesses pessoais ou nacionais. $\mathrm{O}$ autor acrescenta que essa característica conferia importância e dignidade ímpares à forma como o profetismo se manifestava em Israel (SICRE, 1998). 
Justamente por não se isentarem de proclamar aquilo que lhes fora revelado como vontade divina, podemos ler vários textos em que os profetas condenam a ostentação e o despotismo dos reis, bem como o favorecimento do sincretismo religioso e cultural (IBAÑEZ, 1998). Também encontramos, nos textos bíblicos, vários relatos de indisposições entre profetas e sacerdotes. Enquanto estes representam a institucionalização e profissionalização da religião, o profeta era "uma personagem carismática com uma religiosidade interiorizada e espiritual, amigo das reformas e contrário às posturas intransigentes da oficialidade" (MAYORAL, 1998, p. 48).

De fato, se analisarmos as denúncias feitas pelos profetas no Primeiro Testamento, perceberemos que a falta de associação entre práticas cúlticas e atos de justiça e direito é um de seus temas de maior repetição. Para eles, qualquer culto que seja oferecido por um indivíduo que não pratique os termos da aliança e não tenha uma vida justa, será considerado falso e blasfemo. Esse tipo de hipocrisia, na ética dos profetas, não ficará sem retribuição (MAYORAL, 1998).

É necessário ressaltar que o profetismo no Primeiro Testamento se caracteriza pela multiplicidade de matizes. Alguns profetas que eram ligados ao templo e à corte, como por exemplo, Natan e Gade na corte de Davi. Outros tinham uma atuação mais próxima ao povo comum, fora dos círculos cúlticos e monárquicos, cuja obra preservou-se inicialmente através da tradição oral - como Elias e Eliseu, por exemplo. E há os profetas literários, cuja atuação em geral prediz o juízo divino sobre a monarquia e sobre o Estado, como Isaías, Jeremias e Amós (SCHWANTES, 1982).

Neste artigo, interessa-nos particularmente a forma de atuação do profeta Isaías. Henry (2010) relata que, de acordo com a tradição judaica, Isaías era da família real, sendo seu pai irmão do rei Uzias. O autor enfatiza que a leitura de seu livro nos leva a perceber que o profeta passava muito tempo na corte, em especial durante o reinado de Ezequias. Possuindo habilidades de comunicação privilegiadas, seu estilo é mais polido que o dos demais profetas, e em algumas passagens, chega a ser "excessivamente sublime e elevado" (HENRY, 2010, p. 2).

O profeta Isaías, de acordo com seu próprio livro (1.1), teria atuado durante o reinado de Uzias, Jotão, Acaz e Ezequias, reis de Judá. Esse período corresponde, aproximadamente, ao intervalo entre os anos 740 e 700 a.C. Foi contemporâneo de Miqueias, também no reino do Sul, e de Amós e 
Oseias, no reino do Norte. Em seu período de atuação, a principal potência estrangeira ameaçadora era a Assíria (SEVI8VILLA, 1998).

Embora seja costumeiro admitir a historicidade do profeta Isaías, há que se questionar o processo de escrita e edição de seu livro. Embora seja apresentado na Tanakh judaica e na Bíblica cristã como um livro único, relata-nos Cox (s.d.) que desde 1892 é habitual que os estudiosos o dividam em três grandes blocos: o Proto-Isaías (capítulos 1-39), o Dêutero-Isaías (capítulos 40-55) e o Trito-Isaías (capítulos 56-66). Essa divisão se deve a mudanças de estilo, tema e contexto histórico, importantes a ponto de suscitar a hipótese de autores diferentes para estes três conjuntos de capítulos. De acordo com Champlin (2001), muitos eruditos acreditam que Isaías teria sido o responsável pela escrita da primeira porção, enquanto que os discípulos de sua escola profética, ao longo do tempo, foram acrescentando novos conteúdos ao volume original.

O Proto-Isaías (capítulos 1-39) apresenta Judá e Israel como reinos independentes. A Assíria era a potência internacional dominantes. Fatos históricos como a guerra siro-efraimita, a queda do Reino do Norte e a invasão de Senaqueribe conferem ao relato certa unidade histórica e contextual (COX, s.d.).

O Dêutero-Isaías (capítulos 40-55) é uma coletânea de poemas, em estilo rapsódico, cujo contexto aproxima-se do período do exílio de Judá. São feitas alusões a Ciro e à iminente queda da Babilônia, levando certos estudiosos a questionar se realmente se tratavam de profecias, ou de um relato histórico (CHAMPLIN, 2001). Nesse caso, estes trechos poderiam ter sido escritos à época do cativeiro babilônico (SEVILLA, 1998).

O Trito-Isaías (capítulos 56-66) também é uma coletânea de poemas, bastante semelhante à porção anterior - o que leva alguns eruditos a crerem que possui a mesma autoria. Porém, esses capítulos refletem um pensamento escatológico mais avançado, que não seria comum à época do exílio. O maior interesse pelo culto nessa porção do livro também pode associá-lo à época de Ageu e Zacarias, por exemplo (CHAMPLIN, 2001).

Há que se ressaltar que nem todos os estudiosos do livro de Isaías concordam com a possibilidade de que o mesmo tenha sido escrito por autores distintos. Ridderbos (1990) e Cozzer (2014) são exemplos desse ponto de vista. A seguir, apresentaremos algumas refutações ao Dêutero-Isaías.

Cozzer (2014) critica, em primeiro lugar, a negação da possibilidade de que Isaías tivesse previsto fatos mais distantes do que o contexto em que ele 
vivia. Conforme Ridderbos (1990), ele deve ter falecido em torno de 701 a.C., e a invasão da Babilônia pela Pérsia não se deu antes de 539 a.C.. Champlin (2001) acrescenta que, para os críticos, a citação nominal de Ciro já é, por si, indicador de que o texto foi escrito durante o cativeiro. Essa suposição limita a possibilidade de que um profeta tenha visões do futuro remoto. Considerando o conceito de profeta e profecia como agentes reveladores do vindouro por intermédio divino, embora a revelação de nomes seja incomum, não deve ser considerada impossível.

Acerca das diferenças de estilo entre os três blocos de Isaías, Cozzer (2014) argumenta que o estilo de um autor pode variar de acordo com sua idade, contexto social, destinatário e assunto. A essa proposição, Champlin (2001) acrescenta o questionamento acerca do nível de conhecimento do idioma hebraico por parte dos críticos, que podem estar se baseando em conjecturas infundadas. Cozzer (2014) acrescenta ainda que diversas expressões idiomáticas, palavras e frases, bem como algumas concepções teológicas se repetem ao longo de todo o livro de Isaías. E não encontramos, nos capítulos 40 a 66, referências que demonstrem familiaridade com o ambiente babilônico, como no livro de Ezequiel.

Acrescente-se ainda, a estes argumentos, testemunhos de integridade do livro. Ridderbos (1990) analisou, no Primeiro e no Segundo Testamentos, todas as citações do livro de Isaías. Nenhuma delas sugere a existência de mais de um escritor para as profecias. Pelo contrário, vários trechos contidos entre os capítulos 40 e 66 são atribuídos ao profeta por diferentes personagens neotestamentários. E o livro é sempre referido como o rolo do profeta Isaías, sem qualquer referência a alguma divisão. Cozzer (2014) acrescenta ainda o fato de que a cópia de Isaías encontrada entre os Manuscritos do Mar Morto não possui nenhuma interrupção entre os capítulos 39 e 40, indicando que a comunidade de Qumran o interpretava como sendo um único livro.

Podemos concluir, dessa controvérsia, que embora haja uma sensível mudança de estilo, assunto e argumento teológico entre os três blocos textuais, existe também argumentos consistentes favoráveis à interpretação tradicional do livro como de única autoria. Conforme descreve Champlin (2001), todos os manuscritos antigos apresentam o livro como uma unidade, e não há evidências históricas da atuação de uma escola profética de Isaías. Dessa forma, optamos nesse trabalho por considerar as evidentes diferenças literárias e teológicas entre os blocos textuais, mas sem fazer qualquer afirmação conclusiva a respeito de sua autoria. 
O trecho que pretendemos examinar nesse trabalho localiza-se justamente no chamado Dêutero-Isaías. Ridderbos (1990) relata que esse trecho menciona o exílio dos judeus na Babilônia; o reinado de Ciro, o persa, e suas conquistas e vitórias sobre muitas nações e reis; a invasão da Babilônia e libertação dos judeus; o retorno dos exilados e a reconstrução de Jerusalém. Todos os fatos preditos pelo profeta nesse trecho subentendem o exílio babilônico como realidade histórica, à qual se sucederão novos acontecimentos.

Champlin (2001) considera que o versículo que pretendemos analisar neste trabalho (Isaías 45.7) faz parte de um poema (44.24 a 45.13) sobre Ciro, cuja atuação e exércitos fizeram a história da humanidade mudar para outro plano. A primeira estrofe (44.24-28) seria uma declaração introdutória; a segunda (45.1-7) discorreria acerca da missão de Ciro, e a terceira (45. 9-13) celebraria a soberania divina sobre a natureza e a história ${ }^{1}$.

É interessante observar que, embora não concordem na forma de dividir o texto profético, Ridderbos (1990), Champlin (2001) e Henry (2010) concordam que este trecho é claro ao indicar a soberania divina sobre os tempos e a história. Dessa forma, o chamado de Ciro - um gentio que não conhecia o Deus de Israel - inaugura uma era de transformações que permitirão o cumprimento de um novo ciclo de propósitos divinos para o povo de Israel e para o mundo.

Champlin (2001) resume em cinco pontos a missão divina atribuída a Ciro: liberar o mundo do domínio babilônico; vingar suas barbaridades; libertar Judá do cativeiro e tornar possível a restauração de Jerusalém e Judá; através da restauração dos judeus preparar a vinda do Messias; e transferir o poder da civilização às nações de língua indo-europeia, aproximando-se mais do Ocidente. Para o autor, Ciro foi a mão de Deus em todos esses propósitos.

A segunda parte do poema (45.1-7), de acordo com Champlin (2001), descreve as conquistas impostas por Ciro a várias nações, inclusive à Babilônia. O poderio de humilhar governantes, a conquista das portas de reinos - inclusive as lendárias cem portas de Babilônia, a aquisição do reino mais rico do mundo à época. Tudo seria concedido por Deus a um gentio, que é chamado de "ungido" (45.1): título inédito, em todo o Primeiro Testamento, a alguém nessa condição (CHAMPLIN, 2001).

Todos esses privilégios lhe seriam concedidos não por seus próprios méritos, mas porque Deus o havia escolhido para beneficiar Israel. O Senhor 1 O autor não inclui o versículo 8 na divisão do poema, estudando-o separadamente como
Hino à Salvação Universal. 
o chamou, o ungiu, o fortaleceu e o comissionou para todas suas obras, a fim de que seu povo Israel se beneficiasse dos resultados desses acontecimentos (RIDDERBOS, 1990).

O versículo que estudamos nesse artigo é a conclusão da segunda parte do poema sobre Ciro. Nesse contexto, ele simboliza um manifesto sobre a onipotência divina (HENRY, 2010). Percebe-se, porém, que o sentido aponta para uma situação de guerra: conquistas e libertações, soerguimento e abatimento. Entre vencedores e vencidos, Deus é quem controla o bem e o mal - sempre de acordo com um propósito estabelecido.

\section{Aspectos linguísticos}

Iniciaremos, portanto, apresentando o versículo que é objeto deste escrutínio.

Quadro 1 - Texto hebraico, transliteração e tradução literal de Isaías 45.7

\begin{tabular}{|c|c|c|}
\hline Tradução literal & Transliteração & Texto hebraico \\
\hline $\begin{array}{l}\text { Formo luz e crio trevas } \\
\text { faço paz e crio mal } \\
\text { eu YHVH faço tudo isto }\end{array}$ & $\begin{array}{l}\text { Yotzer 'or uvore' khoshech } \\
\text { 'oseh shalom uvore' ra' } \\
\text { 'ani YHVH 'oseh chal-'eleh. }\end{array}$ & 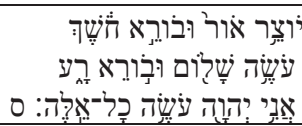 \\
\hline
\end{tabular}

É possível perceber que o verso é composto por um tricolon. O primeiro e o segundo colon utilizam a antinomia como elemento estruturador (luz X trevas; paz X mal). Porém, quando comparados entre si, percebemos que os dois colons constroem um paralelismo sinônimo, em que as duas afirmações concorrem para um mesmo sentido. Nesse caso, o conceito de luz é comparado ao de paz, enquanto que o de trevas é relacionado ao de mal.

A escolha de vocabulário presente nos dois primeiros colons transmite uma ideia de totalidade. Essa ideia é reforçada pelo uso da antítese, e também pela oposição entre materialidade (luz e trevas como perceptíveis pelos sentidos) e subjetividade (paz e mal como produto de interpretação). Autores como Ridderbos (1990), Champlin (2001) e Henry (2010) corroboram a interpretação dos referidos colons como construtores da ideia de totalidade.

O terceiro colon é considerado por Ridderbos (1990, p. 374), uma "conclusão apoteótica". Este trecho também enfatiza o conceito de totalidade

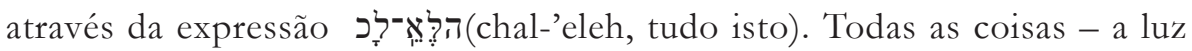
e as trevas, o bem e o mal - são atribuídas a Deus, apresentado como seu criador e, consequentemente, seu controlador. 
Ao interpretar esse versículo, Champlin (2001) e Henry (2010) consideram que a totalidade figurada na construção linguística demonstra que Deus é criador e controlador do bem e do mal. Cabe observar que o primeiro autor considera que a afirmação é uma construção teológica empobrecida, que vê Deus como a causa única para todas as coisas, e que será superada com o avanço teológico para a introdução de causas secundárias. Influenciado pelo pensamento platônico, Champlin considera impossível atribuir a origem do mal a um Deus bondoso. Henry (2010, p. 207), por sua vez, diferencia o mal do pecado - que, para o autor, não pode ter sua autoria atribuída a Deus dos males e tribulações cotidianos. Para o autor, esse versículo não trata da questão da origem do pecado, e sim das bênçãos e males experimentados ao longo da vida, e da mistura de alegrias e tristezas, ora mais pendente para um lado, ora para o outro.

Em todo caso, é comum perceber no Primeiro Testamento - e mesmo no Segundo, em trechos como Romanos 9 - construções teológicas que veem Deus como causa única para todas as coisas. É possível que essas afirmações se relacionem mais com a onipotência e o controle divino, que com a questão moral da existência do mal. Note-se, por exemplo, a questão da separação entre luz e trevas e criação do dia e da noite (Gênesis 1), de acordo com Smith (2001):

Nós, hoje, tentamos compreender a luz pela astronomia e física. No Antigo Testamento pensava-se no âmbito dos fenômenos observáveis. A luz não dispersou todas as trevas. Ela foi considerada "boa" no versículo 4 e separada das trevas. Trevas pode encerrar uma implicação de "mal" em oposição à "boa luz". Quando Deus chamou a luz "dia" e as trevas "noite", exerceu sua soberania sobre elas. No mundo antigo, o poder de dar nome indicava poder de governo. (SMITH, 2001, p. 172. Aspas originais.).

Dessa forma, é possível que trechos como o de Isaías 45.7 refiram-se a Deus como criador das trevas e do mal como forma de demonstrar seu absoluto poder e controle sobre todas as coisas - mesmo as mais indesejáveis.

Prosseguimos esta pesquisa realizando uma breve análise gramatical do texto em questão, com o auxílio de Davidson (s.d.). 
Quadro 2 - Análise gramatical de Isaías 45.7

\begin{tabular}{|c|c|c|c|}
\hline Tradução & Classificação gramatical & Transliteração & $\begin{array}{c}\text { Texto } \\
\text { Hebraico }\end{array}$ \\
\hline Formo & Qal particípio ativo masculino singular rcy (ytzr) & Yotzer & יוצֵר \\
\hline Luz & Substantivo masculino singular & 'or & אור \\
\hline E crio & $\begin{array}{l}\text { Conjunção + Qal particípio ativo masculino singular )rb } \\
\text { (br') }\end{array}$ & uvore' & 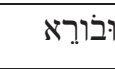 \\
\hline Trevas & Substantivo masculino singular & Khoshech & 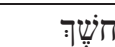 \\
\hline Faço & Qal particípio ativo masculino singular & 'oseh & עלעׁה \\
\hline Paz & Substantivo masculino singular & shalom & שֶׁלוֹם \\
\hline E crio & $\begin{array}{l}\text { Conjunção + Qal particípio ativo masculino singular )rb } \\
\text { (br') }\end{array}$ & uvore' & 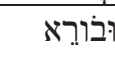 \\
\hline Mal & Substantivo masculino singular & $\mathrm{ra}^{6}$ & רְע \\
\hline $\mathrm{Eu}$ & Pronome pessoal $1^{\mathrm{a}}$ pessoa do singular & 'ani & אָנִי \\
\hline YHVH & Nome sagrado de Deus & YHVH & 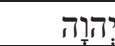 \\
\hline Faço & Qal particípio ativo masculino singular h\&( ('sh) & 'oseh & עלֶֶׁה \\
\hline Tudo & Substantivo masculino singular construto & chal & כָל \\
\hline Isto & Pronome demonstrativo plural & 'eleh & אַלֶּה \\
\hline
\end{tabular}

Identificamos as raízes dos verbos que se referem à atividade criadora,

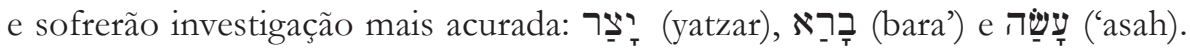
Em Dicionário... (2002), encontramos as seguintes possibilidades de tradução para as raízes, quando conjugadas em Qal:

Quadro 3 - Verbos que remetem à atividade criadora em Isaías 45.7

\begin{tabular}{|l|l|}
\hline \multicolumn{1}{|c|}{ Tradução } & \multicolumn{1}{|c|}{ Verbo } \\
\hline Plasmar, formar, amoldar, criar. & (yatzar) \\
\hline Criar (somente por parte de Deus). & (bara') \\
\hline $\begin{array}{l}\text { Fazer, manufaturar, trabalhar; pôr, colocar, transformar, } \\
\text { fabricar, aprontar, elaborar, preparar, realizar, executar, } \\
\text { agir, intervir. }\end{array}$ & ('asah) \\
\hline
\end{tabular}

Embora esses verbos possuam significados bastante próximos, uma análise contextualizada pode indicar o significado mais adequado para a tradução. Para isso, recorremos a Harris, Archer Jr. e Waltke (1998), que analisam as ocorrências das raízes no Antigo Testamento, bem como suas implicações teológicas. 
De acordo com os autores, o sentido básico de רָיָ (yatzar) é formar, modelar. Refere-se tanto à agência humana quanto divina. Pode aludir à formação material de algo (por exemplo, modelar um ídolo em Isaías 44.9, ou a criação do homem a partir do pó da terra, em Gênesis 2.7-8), e também à formação de planos, sobretudo da parte de Deus (como em Isaías 37.26). Quando a raiz se refere aos objetos do trabalho criador de Deus, sua ênfase recai sobre a ação de dar forma ou estruturar esses fenômenos. Pode ser utilizada como substituto para ברָָ (bara'), mas não lhe é um sinônimo exato (HARRIS; ARCHER JR.; WALTKE, 1998).

בְר (bara'), por sua vez, tem a conotação de criar. Pode também referir-se a iniciar algo novo, ou trazer à existência. Em qal, é utilizado apenas para aludir à atividade de Deus - os autores chegam a associá-lo, inclusive, ao conceito do fiat divino. É frequentemente usada para referir-se à criação do universo e dos fenômenos naturais. Por essa característica, a raiz assume relevância teológica, uma vez que a criação é sempre indicada como exemplificadora da magnitude do poder de Deus. De acordo com os autores, "o termo empresta-se bem ao conceito de criação ex nibilo, embora tal conceito não seja necessariamente inerente ao sentido da palavra" (HARRIS; ARCHER JR.; WALTKE, 1998, p. 213). Acresça-se a esta definição que, de acordo com o relato de Smith (2001), no Primeiro Testamento só se utiliza esta raiz com o sentido de criar quando o sujeito é Deus. Para o autor, soaria blasfemo caso o sujeito desse verbo fosse um ser humano.

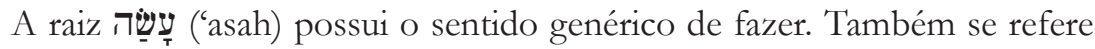
a fabricar ou dar forma, mas permite outras utilizações. Pode ter conotação ética, como por exemplo, fazer o que Deus havia ordenado (Êxodo 23.22). Pode aparecer em expressões específicas, como fazer guerra (Gênesis 14.2), ou observar a Páscoa (Êxodo 12.48). Pode ter o sentido de praticar, referindo-se a um erro (Oseias 6.9) ou a seguir um conselho (II Samuel 17.23). Quando Deus é o sujeito do verbo, em geral se refere ao agir divino na História, executando seu propósito soberano. Embora também seja usado para descrever os aspectos da obra de Deus na criação, não possui a mesma ligação ao conceito de fiat divino que ocorre em בָרָ (bara') (HARRIS; ARCHER JR.; WALTKE, 1998).

Em nossos objetivos, particularmente interessa-nos o emprego desses verbos relacionado à atividade divina. Smith (2001) afirma que, no Oriente Próximo, quatro tipos de linguagem de criação eram comuns: criação por meio de algum tipo de atividade, criação por meio de concepção e nascimento, criação por meio de batalha, e criação por meio da palavra. $\mathrm{O}$ autor associa a 


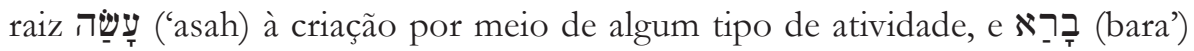
à criação por meio da palavra, enfatizando ser essa raiz desconhecida fora de Israel e do Primeiro Testamento.

Devemos observar que, para se referir à luz e à paz, os verbos utilizados

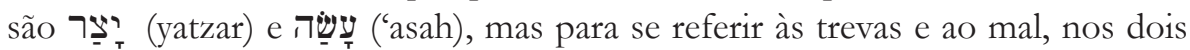

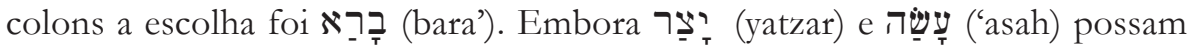

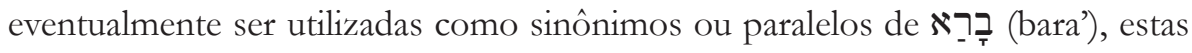
raízes possuem um diferencial profundo: não traduzem a ideia da criação $e x$ nibilo. Assim, podemos afirmar que a escolha de vocabulário nesse versículo procura demarcar e intensificar a ideia de que Deus é o criador do mal.

Esta escolha é bastante peculiar, se considerarmos que no Gênesis, logo após criar (ברָ - bara') os céus e a terra, Deus cria a luz através de sua palavra. Embora o verbo ברָ ברָ (bara') não seja utilizado para descrever este processo, seu sentido está implícito na narrativa. Mesmo porque Gênesis não se ocupa de descrever a partir do que Deus criou a luz. Trata-se, portanto, de um fiat, cujo resultado foi qualificado pelo próprio Deus como bom (1.4).

Em Isaías 45.7, percebemos que a paz e a luz são feitas (ריָ- - yatzar e

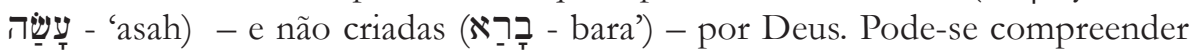
que estas são formadas a partir de coisas que já existem. As trevas e o mal, por sua vez, podem ser criados do nada.

Ora, se as trevas e o mal podem ser criados do nada, e a paz e a luz podem ser formadas a partir do que já existe, depreendemos através deste versículo que as trevas e o mal podem ser a matéria prima que, sob ação divina, dará origem à paz e à luz. Este versículo traz implícita a ideia de transformação: aquilo que é negativo, mediante a soberania divina, pode se tornar algo positivo. Mas, caso Deus julgue pertinente, ele pode criar o mal sem que haja uma origem presumida ou plausível para o mesmo.

Retomando as informações observadas no tópico anterior, podemos concluir que a paz e a luz seriam feitas por Deus a partir daquilo que já era experienciado pelo povo de Israel. Embora o cativeiro e a destruição de Jerusalém fossem uma situação que, a seus olhos, pudesse ser considerada trevas e mal, Deus poderia transformá-los em coisas boas - e parecia desejar começar isso através de Ciro.

Por outro lado, Babilônia, que até então reinava absoluta, veria as trevas e o mal emergirem sobre si, mesmo sem saber de onde viriam. Embora não existisse, naquele momento, nada que a pudesse ameaçar, Deus estava disposto a fazer surgir, como se fosse do nada, alguém comissionado para executar sua vingança e estabelecer seus planos. 


\section{Ocorrência das raízes no Pentateuco}

Passaremos a estudar a ocorrência no Pentateuco dos três verbos escolhidos para análise. A escolha desta porção como trecho de referência para o significado das raízes se deu pelo fato de ser aquela que dá origem à teologia e aos demais escritos do Primeiro Testamento. A mensagem profética embasava-se em uma tradição religiosa e cultural em Israel, que tem na narrativa da criação, dos patriarcas e na lei mosaica seu principal ponto de origem. Esta tradição foi modificada e adaptada às necessidades do povo ao longo de sua história, dando origem a movimentos como o profetismo, e às construções teológicas que lhe são inerentes. Por essas razões, consideramos que o Pentateuco é a porção mais apropriada e significativa para uma análise comparativa.

Com o auxílio de Wigram (1955), procuramos identificar quantas

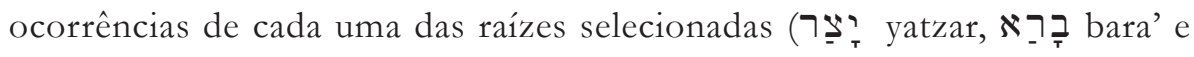

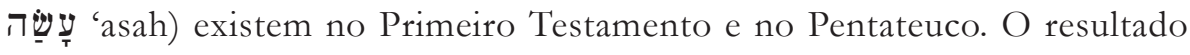
pode ser visualizado no Quadro 4.

Quadro 4 - Ocorrências das raízes

\begin{tabular}{|c|c|c|}
\hline Pentateuco & Primeiro Testamento & Raiz \\
\hline 04 & 63 & רי \\
\hline 14 & 1254 & ברצ \\
\hline $23^{2}$ & 2628 & עשצ \\
\hline
\end{tabular}

Ao que se pode perceber, essas raízes não são muito frequentes no Pentateuco. Considerando que esta porção equivale a cerca de $20 \%$ do Primeiro Testamento ${ }^{3}$, o número de ocorrências das raízes é bem pequeno - cerca de 6\% das ocorrências de יצר (ytzr) e cerca de 1\% das ocorrências de raiz עשוֹ (br') e ('sh). Tal fato possui uma perspectiva negativa, pois não oferece muitas ocorrências para comparação da forma como as raízes são empregadas. Mas oferece também uma perspectiva positiva, possibilitando que se analise a totalidade das ocorrências.

\footnotetext{
2 Refere-se apenas a ocorrências da mesma raiz e forma verbal que ocorrem no Livro de Isaías.

3 Cálculo feito a partir do número de capítulos de cada livro.
} 
Cabe observar que foram consideradas as ocorrências das raízes

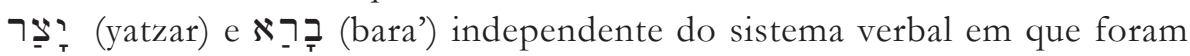
empregadas. Mesmo porque, no Pentateuco, não ocorre nenhuma vez a

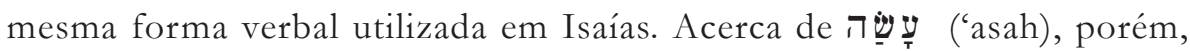
foi necessário delimitar a pesquisa à mesma forma verbal presente no texto profético (הֶָׁ , 'oseh, Qal particípio ativo masculino singular), devido ao elevadíssimo número de ocorrências da raiz em todo o Primeiro Testamento.

A seguir, apresentaremos tabelas com as ocorrências das raízes no Pentateuco, acompanhadas da forma como as mesmas são usualmente traduzidas para o português. Para melhor visualização, as formas verbais em português que traduzem as raízes analisadas estão destacadas em negrito. Utilizou-se, para esta comparação, a Nova Versão Internacional. Começaremos por רִיז? (yatzar).

\section{Quadro 5 - Ocorrências de רָֻ? (yatzar)}

\begin{tabular}{|l|l|}
\hline \multicolumn{2}{|l|}{ רצ' (YTZR) } \\
\hline Gênesis 2.7 & $\begin{array}{l}\text { Então, formou o SENHOR Deus ao homem do pó da terra e lhe soprou } \\
\text { nas narinas o fôlego de vida, e o homem passou a ser alma vivente. }\end{array}$ \\
\hline Gênesis 2.8 & $\begin{array}{l}\text { E plantou o SENHOR Deus um jardim no Éden, na direção do Oriente, } \\
\text { e pôs nele o homem que havia formado. }\end{array}$ \\
\hline Gênesis 2.19 & $\begin{array}{l}\text { Havendo, pois, o SENHOR Deus formado da terra todos os animais do } \\
\text { campo e todas as aves dos céus, trouxe-os ao homem, para ver como este } \\
\text { lhes chamaria; e o nome que o homem desse a todos os seres viventes, } \\
\text { esse seria o nome deles. }\end{array}$ \\
\hline Exxodo 32.4 & $\begin{array}{l}\text { Este, recebendo-as das suas mãos, trabalhou o ouro com buril e fez dele } \\
\text { um bezerro fundido. Então, disseram: São estes, ó Israel, os teus deuses } \\
\text { que te tiraram da terra do Egito. }\end{array}$ \\
\hline
\end{tabular}

Ao que se pode perceber, todas as ocorrências da raiz no Pentateuco referem-se a fazer algo a partir de um material que já existe. Em Gênesis, especificamente, Deus é o sujeito de todas as ocorrências do verbo. יצר (ytzr) é utilizado para referir-se à criação do ser humano e dos animais a partir de um material já existente, a terra. Note-se que em ambos os casos o verbo foi aplicado para descrever a criação de um ser vivo.

Em Exxodo percebemos um esquema semelhante na utilização do verbo. A partir do ouro já existente, Arão trabalha e faz um bezerro fundido. 
Embora fosse claro que não se tratava de uma criatura viva no sentido estrito da palavra, à imagem é atribuída a personificação da divindade que tirou Israel do Egito - ou seja, de certa forma, tratava-se de alguém que era considerado vivo e real pelos participantes de seu culto.

\section{Quadro 6 - Ocorrências de ברא (br')}

\begin{tabular}{|c|c|}
\hline \multicolumn{2}{|r|}{ ברא (BR') } \\
\hline Gênesis 1.1 & No princípio, criou Deus os céus e a terra. \\
\hline Gênesis 1.21 & $\begin{array}{l}\text { Criou, pois, Deus os grandes animais marinhos e todos os seres viventes } \\
\text { que rastejam, os quais povoavam as águas, segundo as suas espécies; e } \\
\text { todas as aves, segundo as suas espécies. E viu Deus que isso era bom. }\end{array}$ \\
\hline Gênesis 1.27 & $\begin{array}{l}\text { Criou Deus, pois, o homem à sua imagem, à imagem de Deus o criou; } \\
\text { homem e mulher os criou. }\end{array}$ \\
\hline Gênesis 2.3 & $\begin{array}{l}\text { E abençoou Deus o dia sétimo e o santificou; porque nele descansou } \\
\text { de toda a obra que, como Criador, fizera. }\end{array}$ \\
\hline Gênesis 2.4 & $\begin{array}{l}\text { Esta é a gênese dos céus e da terra quando foram criados, quando o } \\
\text { SENHOR Deus os criou. }\end{array}$ \\
\hline Gênesis 5.1 & $\begin{array}{l}\text { Este é o livro da genealogia de Adão. No dia em que Deus criou o } \\
\text { homem, à semelhança de Deus o fez; }\end{array}$ \\
\hline Gênesis 5.2 & $\begin{array}{l}\text { homem e mulher os criou, e os abençoou, e lhes chamou pelo nome } \\
\text { de Adão, no dia em que foram criados. }\end{array}$ \\
\hline Gênesis 6.7 & $\begin{array}{l}\text { Disse o SENHOR: farei desaparecer da face da terra o homem que criei, o } \\
\text { homem e o animal, os répteis e as aves dos céus, porque me arrependo } \\
\text { de os haver feito. }\end{array}$ \\
\hline Éxodo 34.10 & $\begin{array}{l}\text { Então, disse: Eis que faço uma aliança; diante de todo o teu povo farei } \\
\text { maravilhas que nunca se fizeram em toda a terra, nem entre nação } \\
\text { alguma, de maneira que todo este povo, em cujo meio tu estás, veja a } \\
\text { obra do SENHOR, porque coisa terrível é o que faço contigo. }\end{array}$ \\
\hline $\begin{array}{l}\text { Números } \\
16.30\end{array}$ & $\begin{array}{l}\text { Mas, se o SENHOR criar alguma coisa inaudita, e a terra abrir a sua boca } \\
\text { e os tragar com tudo o que é seu, e vivos descerem ao abismo, então, } \\
\text { conhecereis que estes homens desprezaram o SENHOR. }\end{array}$ \\
\hline $\begin{array}{l}\text { Deuteronô- } \\
\text { mio } 4.32\end{array}$ & $\begin{array}{l}\text { Agora, pois, pergunta aos tempos passados, que te precederam, desde o } \\
\text { dia em que Deus criou o homem sobre a terra, desde uma extremidade } \\
\text { do céu até à outra, se sucedeu jamais coisa tamanha como esta ou se se } \\
\text { ouviu coisa como esta. }\end{array}$ \\
\hline
\end{tabular}


A raiz ברא (br'), por sua vez, é utilizada em Gênesis para enfatizar que Deus é o criador, tanto da raça humana, quanto dos animais e de tudo que existe. Pode-se concluir, da forma como a raiz é utilizada, que sua ênfase se assenta no poder divino enquanto criador, e não no processo que foi utilizado para criar. Esse poder é tão absoluto que, quando Deus decide destruir a vida na terra (Gênesis 6.7), a raiz aparece novamente para recordar desta prerrogativa.

Para além de Gênesis, ברא (br’) aparece apenas mais três vezes no Pentateuco. É notório que nas três ocorrências a raiz se relaciona com fatos maravilhosos, bons ou maus. Em Êxodo, ela aparece como uma promessa divina de fazer coisas novas e extraordinárias em favor do povo com quem firmara aliança. Em Números, é utilizada para referir-se à forma incomum de morte que receberiam aqueles que se opuseram ao sacerdócio de Arão. Em Deuteronômio, embora a raiz refira-se à criação do homem como forma de marcar o tempo, o contexto deste versículo e dos seguintes refere-se às maravilhas, sinais e milagres feitos por Deus no meio do povo de Israel, como forma de construir-lhes a fé.

Conclui-se, portanto, que ברא (br’) sempre é utilizado em contextos que demonstram o poderio divino: seja para criar, para destruir, ou para fazer maravilhas inesperadas.

Quadro 7 - Ocorrências de עשושה ('sh)

\begin{tabular}{|l|l|}
\hline \multicolumn{2}{|c|}{ | ('SH) } \\
\hline Gênesis 1.11 & $\begin{array}{l}\text { E disse: Produza a terra relva, ervas que dêem semente e árvores } \\
\text { frutíferas que dêem fruto segundo a sua espécie, cuja semente esteja } \\
\text { nele, sobre a terra. E assim fez. }\end{array}$ \\
\hline Gênesis 1.12 & $\begin{array}{l}\text { A terra, pois, produziu relva, ervas que davam semente segundo } \\
\text { a sua espécie e árvores que davam fruto, cuja semente estava nele, } \\
\text { conforme a sua espécie. E viu Deus que isso era bom. }\end{array}$ \\
\hline Gênesis 18.17 & Disse o SENHor: ocultarei a Abraão o que estou para fazer... \\
\hline Gênesis 21.22 & $\begin{array}{l}\text { Por esse tempo, Abimeleque e Ficol, comandante do seu exército, } \\
\text { disseram a Abraão: Deus é contigo em tudo o que fazes;... }\end{array}$ \\
\hline Gênesis 31.12 & $\begin{array}{l}\text { Ele continuou: Levanta agora os olhos e vê que todos os machos } \\
\text { que cobrem o rebanho são listrados, salpicados e malhados, porque } \\
\text { vejo tudo o que Labão te está fazendo. }\end{array}$ \\
\hline
\end{tabular}




\begin{tabular}{|c|c|}
\hline Gênesis 39.3 & $\begin{array}{l}\text { Vendo Potifar que o SENHOR era com ele e que tudo que ele fazia o } \\
\text { SENHOR prosperava em suas mãos,... }\end{array}$ \\
\hline Gênesis 39.22 & $\begin{array}{l}\text {...o qual confiou às mãos de José todos os presos que estavam no } \\
\text { cárcere; e ele fazia tudo quanto se devia fazer ali. }\end{array}$ \\
\hline Gênesis 39.23 & $\begin{array}{l}\text { E nenhum cuidado tinha o carcereiro de todas as coisas que estavam } \\
\text { nas mãos de José, porquanto o SENHOR estava com ele, e tudo o que } \\
\text { ele fazia o SENHOR prosperava. }\end{array}$ \\
\hline Gênesis 41.25 & $\begin{array}{l}\text { Então, lhe respondeu José: O sonho de Faraó é apenas um; Deus } \\
\text { manifestou a Faraó o que há de fazer. }\end{array}$ \\
\hline Gênesis 41.28 & $\begin{array}{l}\text { Esta é a palavra, como acabo de dizer a Faraó, que Deus manifestou } \\
\text { a Faraó que ele há de fazer. }\end{array}$ \\
\hline$\hat{\text { Exxodo } 15.11}$ & $\begin{array}{l}\text { Ó SENHOR, quem é como tu entre os deuses? Quem é como tu, } \\
\text { glorificado em santidade, terrível em feitos gloriosos, que operas } \\
\text { maravilhas? }\end{array}$ \\
\hline$\hat{\text { Exxodo } 18.14}$ & $\begin{array}{l}\text { Vendo, pois, o sogro de Moisés tudo o que ele fazia ao povo, disse: } \\
\text { Que é isto que fazes ao povo? Por que te assentas só, e todo o povo } \\
\text { está em pé diante de ti, desde a manhã até o pôr-do-sol? }\end{array}$ \\
\hline Exxodo 18.17 & O sogro de Moisés, porém, lhe disse: Não é bom o que fazes,... \\
\hline Exxodo 34.10 & $\begin{array}{l}\text { Então, disse: Eis que faço uma aliança; diante de todo o teu povo farei } \\
\text { maravilhas que nunca se fizeram em toda a terra, nem entre nação } \\
\text { alguma, de maneira que todo este povo, em cujo meio tu estás, veja a } \\
\text { obra do SENHOR; porque coisa terrível é o que faço contigo. }\end{array}$ \\
\hline $\begin{array}{l}\text { Números } \\
11.15\end{array}$ & $\begin{array}{l}\text { Se assim me tratas, mata-me uma vez, eu te peço, se tenho achado } \\
\text { favor aos teus olhos; e não me deixes ver a minha miséria. }\end{array}$ \\
\hline $\begin{array}{l}\text { Números } \\
24.18\end{array}$ & $\begin{array}{l}\text { Edom será uma possessão; Seir, seus inimigos, também será uma pos- } \\
\text { sessão; mas Israel fará proezas. }\end{array}$ \\
\hline $\begin{array}{l}\text { Deuteronômio } \\
10.18\end{array}$ & $\begin{array}{l}\text {...que faz justiça ao órfão e à viúva e ama o estrangeiro, dando-lhe } \\
\text { pão e vestes. }\end{array}$ \\
\hline $\begin{array}{l}\text { Deuteronômio } \\
18.12\end{array}$ & $\begin{array}{l}\text {...pois todo aquele que faz tal coisa é abominação ao SENHOR; e por } \\
\text { estas abominações o SENHOR, teu Deus, os lança de diante de ti. }\end{array}$ \\
\hline $\begin{array}{l}\text { Deuteronômio } \\
22.5\end{array}$ & ...porque qualquer que faz tais coisas é abominável ao SENHOR, teu Deus. \\
\hline $\begin{array}{l}\text { Deuteronômio } \\
25.16\end{array}$ & $\begin{array}{l}\text { Porque é abominação ao SENHOR, teu Deus, todo aquele que pratica } \\
\text { tal injustiça. }\end{array}$ \\
\hline $\begin{array}{l}\text { Deuteronômio } \\
31.21\end{array}$ & $\begin{array}{l}\text {...e, quando o tiverem alcançado muitos males e angústias, então, este } \\
\text { cântico responderá contra ele por testemunha, pois a sua descendência, } \\
\text { sempre, o trará na boca; porquanto conheço os desígnios que, hoje, } \\
\text { estão formulando, antes que o introduza na terra que, sob juramento, } \\
\text { prometi. }\end{array}$ \\
\hline
\end{tabular}


עשה ('sh), por sua vez, é uma raiz extremamente comum em todo o Primeiro Testamento. Em geral, não possui nenhum significado especial - apenas a ideia de fazer, praticar. É um verbo que demonstra ação, procedimento, forma de agir. Em certa medida, demonstra ações costumeiras e próprias de um indivíduo - observe que pode ser utilizado para referir ao fruto produzido pela árvore (Gênesis 1.12). Também pode ser utilizado para referir ao pensamento, posto que é anterior à ação (Deuteronômio 31.21).

Retomando os resultados anteriores sobre o trecho de Isaías à luz dos conhecimentos obtidos pelo estudo das ocorrências das raízes no Pentateuco, concluímos que o uso da raiz יצר (ytzr) reforça a ideia de criação a partir de algo que já existe. Confirma-se, portanto, que a expressão "eu formo a luz" faz referência à criação da luz a partir da realidade já existente. Cabe, porém, observar que o Pentateuco tem certa predileção por utilizar este verbo para referir-se à criação de seres vivos, ou a quem a vida é atribuída, como no caso dos ídolos. Dessa forma, suscitamos o questionamento acerca da natureza dessa luz. Seria ela uma personificação de todas as coisas boas, ou representaria um indivíduo capaz de trazer ou promover essas coisas boas?

Prosseguindo, percebemos que ברא (br’) é utilizado apenas para referirse à parte menos desejável do versículo: "crio as trevas", "crio o mal". Estas expressões podem ser vistas como uma manifestação do poder divino, e de sua prerrogativa enquanto criador: se Deus criou o mundo, e pôde fazer coisas boas, ele também pode fazer as coisas más. Mesmo que para isso seja necessário agir de uma forma extraordinária, maravilhosa e inesperada.

O trecho "eu faço (עשה, 'sh) a paz" pode trazer consigo a ideia de que Deus pratica a paz, ou seja, que faz parte de suas ações habituais - e até de seus planos - promover a paz. Embora ele criasse as trevas e o mal, deveria proceder fazendo a paz. Independente do cenário caótico que estava por vir, havia também a certeza de que no final de tudo Deus promoveria a paz. A utilização de עשֶה ('sh) na conclusão do versículo ressalta que a alternância entre a luz e as trevas, a paz e o mal são obras de Deus, e que esse é o seu agir habitual.

\section{Isaías 45.7 nas Bíblias brasileiras}

Após aprofundar o conhecimento sobre este versículo, aproximandonos mais do sentido que apresentava aos primeiros ouvintes, cabe-nos questionar o quanto as traduções bíblicas atualmente comercializadas são capazes de apresentar a riqueza envolvida na leitura deste trecho. Com tal 
intuito, elencamos cinco versões, entre católicas e protestantes. O Quadro 8 apresenta o versículo estudado em cada uma delas.

Quadro 8 - Diferentes traduções para Isaías 45.7

\begin{tabular}{|l|l|}
\hline \multicolumn{1}{|c|}{ Tradução } & \multicolumn{1}{c|}{ Texto de Isá́as 45.7 } \\
\hline $\begin{array}{l}\text { Almeida Revista e } \\
\text { Corrigida (1995) }\end{array}$ & $\begin{array}{l}\text { Eu formo a luz e crio as trevas; eu faço a paz e crio o mal; } \\
\text { eu, o SENHOR, faço todas estas coisas. }\end{array}$ \\
\hline $\begin{array}{l}\text { Almeida Revista e } \\
\text { Atualizada (2008) }\end{array}$ & $\begin{array}{l}\text { Eu formo a luz e crio as trevas; faço a paz e crio o mal; } \\
\text { eu, o SENHOR, faço todas estas coisas. }\end{array}$ \\
\hline CNBB & $\begin{array}{l}\text { Eu é que formo a luz e crio as trevas, faço o bem-estar } \\
\text { e crio o sofrimento; eu sou o SENHOR, eu é que faço } \\
\text { tudo isso. }\end{array}$ \\
\hline $\begin{array}{l}\text { Nova Versão Interna- } \\
\text { cional }\end{array}$ & $\begin{array}{l}\text { Eu formo a luz e crio as trevas, promovo a paz e causo a } \\
\text { desgraça; eu, o SENHOR, faço todas essas coisas. }\end{array}$ \\
\hline Ave Maria (1992) & $\begin{array}{l}\text { ‥formei a luz e criei as trevas, busco a felicidade e suscito } \\
\text { a infelicidade. Sou eu o Senhor, que faço todas essas coisas. }\end{array}$ \\
\hline $\begin{array}{l}\text { Nova Tradução na } \\
\text { Linguagem de Hoje }\end{array}$ & $\begin{array}{l}\text { Eu sou o Criador da luz e da escuridão e mando bênçãos } \\
\text { e maldições; eu, o SENHOR, faço tudo isso. }\end{array}$ \\
\hline Bíblia Viva (2002) & $\begin{array}{l}\text { Eu crio a luz e a escuridão. Eu controlo todos os acon- } \\
\text { tecimentos, os bons e os maus. Eu, o Senhor é que faço } \\
\text { todas essas coisas. }\end{array}$ \\
\hline
\end{tabular}

Inicialmente, observaremos alguns aspectos da tradução, tais como a forma como foi feita a equivalência de vocabulário entre os idiomas. As traduções Almeida Revista e Corrigida, Almeida Revista e Atualizada e CNBB utilizam verbos diferentes em português para raízes hebraicas diferentes, e traduzem as duas ocorrências de הֶֶׁ ('oseh) e רָר (bara') da mesma forma. Esta escolha do tradutor permite que o leitor em português perceba as variações de vocabulário utilizadas no versículo.

Por outro lado, a Nova Versão Internacional e a Ave Maria optaram por uma tradução menos literal, mais dinâmica e teológica. A escolha dos tradutores não se baseou na rigidez de equivalência do vocabulário, buscando se aproximar mais da interpretação do sentido do texto. Dessa forma, as

4 Disponível no sítio internet Bíblica Católica Online. 
escolhas do vocabulário em português permitem que se perceba mais da teologia da causa única que do vocabulário hebraico.

Apesar das polêmicas que circundam a qualidade da Nova Tradução na Linguagem de Hoje e da Bíblia Viva, estas versões foram incluídas neste trabalho por serem bastante populares entre os brasileiros. A opção dos tradutores foi por apresentar um texto de fácil leitura e compreensão. Assim, não foram mantidas sequer estruturas próprias do texto hebraico, como o paralelismo. Ambas versões assumem que, como os verbos foram postos em paralelo, possuem o mesmo sentido - e optaram por um único verbo para cada dois colons. Teologicamente, as escolhas dos tradutores enfatizam o poderio divino e sobretudo seu controle sobre todas as coisas. Porém, a quebra da poética e empobrecimento do vocabulário impedem que a interpretação do leitor avance mais do que este ponto.

É importante observar que nenhuma tradução é um trabalho de perfeita equivalência entre dois idiomas. Escolhas necessitam ser feitas durante o processo, e cabe ao tradutor decidir qual opção trará menos prejuízos ao sentido do texto e ao leitor. Acerca da equivalência de vocabulário, é necessário observar que aproximar-se da literalidade é uma opção comum entre tradutores. Um exemplo dessa escolha para além da língua portuguesa é a Reina Valera. Por outro lado, devemos considerar que mesmo versões aclamadas por sua qualidade, como a Septuaginta, não traduziram cada raiz hebraica por um único verbo, conforme se pode ver a seguir:

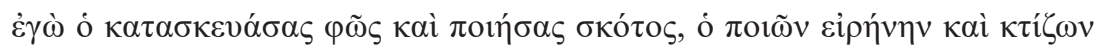

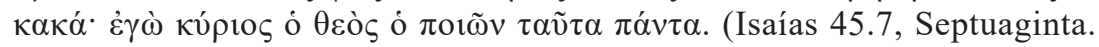
Grifos nossos.)

(Egó ho kataskeuásas fôs kaí poiêsas skótos, ho poiôn eirénen kaí ktízon kaká: egó kyrios ho theós ho poiôn taûta pánta.)

Conforme se pode perceber, uma das mais famosas e aclamadas traduções da

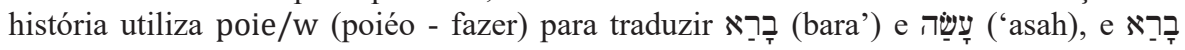
(bara') é traduzido, além de poie/w (poiéo - fazer), por kti/zw (ktízo - criar).

Dessa forma, concluímos que tanto as versões que optaram pela literalidade quanto aquelas que preferiram a aproximação teológica promoveram um contato adequado do leitor com o sentido original do texto. Embora seja impossível, através de uma tradução, alcançar a plena equivalência ou os mesmos resultados que através de uma exegese, estas 
versões permitem uma leitura rica em possibilidades interpretativas e ligações do texto com outros trechos bíblicos.

Por outro lado, também devemos ressaltar as grandes perdas sofridas pelo processo de adequação das versões que privilegiaram uma leitura mais fluída em detrimento da qualidade de tradução. Reconhecemos que essas versões são importantes para determinados segmentos de leitores. Ressaltamos, porém, que a perda de significado linguístico, estilístico e teológico é muito grave, e pode limitar as percepções a respeito do texto, de sua interpretação e de sua inter-relação com outras passagens bíblicas.

\section{Considerações finais}

A beleza e a complexidade do livro de Isaías revelam uma mensagem profética intensa e inusitada. Essas características delineiam a intenção do escritor de ressaltar um pensamento teológico que sobrevaloriza a onipotência divina. Deus é descrito como o criador, a causa única do bem e do mal, o estabelecedor de planos para o futuro das nações, aquele que escolhe um gentio para cumprir seus propósitos, aquele capaz de criar do nada e transformar o que já existe.

O vocabulário escolhido em Isaías 45.7 tem primordial importância na construção desse pensamento. Embora as três raízes utilizadas façam referência à atividade criadora, cada uma possui características próprias, que enriquecem a interpretação do que está sendo descrito. Assim, ressaltamos a importância de que o tradutor considere a riqueza do texto em questão, aproximando nosso idioma ao máximo possível da riqueza do texto hebraico.

Reconhecemos que nenhum trabalho de tradução pode alcançar a perfeição absoluta, dadas as características e peculiaridades de cada idioma. Ainda assim, podemos exaltar o trabalho que deu origem a algumas traduções no idioma português. Embora existam as que primam pela literalidade, e as que tentam se aproximar mais do significado teológico, as versões resultantes demonstram fidelidade ao texto original. Há, porém, versões que focam excessivamente na fluidez de leitura, e que promovem perdas importantes de significado. Sugerimos que estas sejam utilizadas com cautela, pois podem induzir o leitor a uma interpretação única e limitada. 


\section{Referências}

A BÍBLIA Viva. 2. ed. São Paulo: Mundo Cristão, 2002.

ANTIGO Testamento Poliglota: hebraico, grego, português, inglês. São Paulo: Vida Nova; São Paulo: Sociedade Bíblica do Brasil, 2003.

BÍBLIA CATÓLICA ONLINE. Bíblia: tradução CNBB. Disponível em: <http://www. pr.gonet.biz/biblia.php>. Acesso em: 26 out. 2019.

BÍBLIA Sagrada. Nova Tradução na Linguagem de Hoje. Barueri, SP: Sociedade Bíblica do Brasil, 2001.

BÍBLIA Sagrada. Traduzida pelo Centro Bíblico Católico. Revista por Frei João José Pedreira de Castro, O.F.M. São Paulo: Ave Maria, 1992.

BÍBLIA Sagrada. Traduzida por João Ferreira de Almeida. Revista e Atualizada no Brasil. 2. ed. Barueri, SP: Sociedade Bíblica do Brasil, 2008.

BÍBLIA Sagrada. Traduzida por João Ferreira de Almeida. Revista e Corrigida. Rio de Janeiro: CPAD, 1995.

BÍBLIA Sagrada: Nova Versão Internacional. São Paulo: Editora Vida, 2001.

CHAMPLIN, Russell Norman. O Antigo Testamento Interpretado versículo por versículo. Vol. 5. São Paulo: Hagnos, 2001.

COX, Sergio Armstrong. Introducción a los profetas. S.n: S.l., s.d. Disponível em: < https://www.academia.edu/8094571/INTRODUCCI\%C3\%93N_A_LOS_PROFETAS>. Acesso em: 19 jan. 2020.

COZZER, Roney Ricardo. Profetas Maiores: a mensagem profética da Bíblia fala hoje. S.l.: s.n., 2014.

DAVIDSON, B. The analytical hebrew and chaldee lexicon. New York: Harper and Brothers, [s.d.].

DICIONÁRIO Hebraico-Português e Aramaico-Português. São Leopoldo: Sinodal; Petrópolis: Vozes, 2002.

HARRIS, Robert Laird; ARCHER JR.,Gleason Leonard; WALTKE, Bruce. Dicionário Internacional de Teologia do Antigo Testamento. São Paulo: Vida Nova, 1998.

HENRY, Matthew. Comentário Bíblico Antigo Testamento: Isaías a Malaquias. Rio de Janeiro: CPAD, 2010.

IBAÑEZ, Andrés. Os profetas e a política. In: SICRE, José Luis (Org.). Os profetas. São Paulo : Paulinas, 1998. p. 29-43.

LA SANTA Bíblia. Antigua Versión de Casiodoro de Reina revisada por Cipriano de Valera. Revisión de 1960. México, D.F.: Sociedades Bíblicas Unidas, 1989.

MAYORAL, Juan Antonio. O profetismo e o culto. In: SICRE, José Luis (Org.). Os profetas. São Paulo : Paulinas, 1998. p. 45-59. 
PETERLEVITZ, Luciano Robson. Introdução ao Profetismo. Revista Theos, Campinas, 5. Ed., v. 4, n. 1, jun. 2008. p. 1-14.

RIDDERBOS, Jan. Isaías: introdução e comentário. São Paulo: Vida Nova, Mundo Cristão, 1990.

SCHWANTES, Milton. Profecia e Estado - uma proposta para a hermenêutica profética. Estudos Teológicos, São Leoplodo, v. 22, 1982. p. 105-145.

SEVILLA, Cristobal. Um texto sompre vivo. In: SICRE, José Luis (Org.). Os profetas. São Paulo : Paulinas, 1998. p. 113-118.

SICRE, José Luis. Adivinhação e profecia. In: SICRE, José Luis (Org.). Os profetas. São Paulo: Paulinas, 1998. p. 18-28.

SILVA, Cássio Murilo Dias da. Metodologia de exegese bíblica. 2. ed. São Paulo: Paulinas, 2003.

SMITH, Ralph Lee. Teologia do Antigo Testamento: história, método e mensagem. São Paulo: Vida Nova, 2001.

STRONG, James. A concise dictionary of the words in the Greek Testament. Nashville: Abingdon Press, 1890.

STRONG, James. Strong's exhaustive concordance of the bible. Nashville: Abingdon Press, 1890.

VIRKLER, Henry. Hermenêutica Avançada: princípios e processos de interpretação bíblica. São Paulo: Vida, 1998.

WIGRAM, George. The englishman's hebrew concordance of the Old Testament. London: Samuel Bagster and Sons, 1955.

Submetido em: 5-2-2020

Aceito em: 1-6-2021 